\title{
Pattern of inner retinal layers involvement in pigmented paravenous retinochoroidal atrophy as determined by SD-OCT: case report
}

\author{
Padrão de envolvimento das camadas retinianas internas na atrofia retinocoroidiana pigmentada \\ paravenosa determinado pelo SD-OCT: relato de caso
}

Daniela Laura Melo Junqueira ${ }^{1}$, Flavio Siqueira Santos Lopes ${ }^{1,2}$, Luís Gustavo Biteli ${ }^{1,2}$, Tiago Santos Prata ${ }^{1,2}$

\begin{abstract}
Pigmented paravenous retinochoroidal atrophy is an ocular disease characterized by outer retina and choroidal atrophy often with overlying intraretinal bone spicule pigment deposition along the retinal veins. As a rare condition, there is scant information in the literature regarding the pattern of inner retinal layers involvement. We present a case of a 41-year-old white man initially referred for a glaucoma evaluation. Fundoscopy revealed patches of retinochoroidal atrophy and light pigmentation extending from the optic nerve head along the inferior-temporal retinal veins in both eyes. Using different spectral-domain optical coherence tomography (SD-OCT) protocols we identified a significant thinning of the inner retinal layers along the inferior-temporal veins, but with a lucid interval surrounding the optic nerve head. Standard automated perimetry revealed a superior absolute arcuate scotoma sparing the central fixation (good structure-functional correlation). This pattern of inner retinal layers involvement was not previously described. We believe SD-OCT added significantly to the anatomical description of this case. Physicians should consider these new anatomical findings and correlate them with functional status while assessing these patients.
\end{abstract}

Keywords: Atrophy; Retinal ganglion cells; Choroid/pathology; Retina/pathology; Retinal nerve fiber layer; Tomography, optical coherence; Visual field; Case report

\section{RESUMO}

Atrofia retinocoroidiana pigmentada paravenosa é uma doença ocular caracterizada por atrofia localizada da coroide e da retina externa associada a áreas de pigmentação emespícula óssea depositada ao longo das veias retinianas. Comoéuma condição rara há pouca informação na literatura sobreo padrão de envolvimento das camadas mais internas da retina. Relatamos o caso de um homem branco, de 41 anos, encaminhado incialmente para avaliação de glaucoma. Apresentava à fundoscopia áreas de atrofia retinocoroidiana com pigmentação leve sobrejacente, estendendo-se desde o disco óptico e seguindo ao longo da veia temporal inferior da retina em ambos os ol hos. Por meio de diferentes protocolos da tomografia de coerência óptica de domínio espectral (SD-OCT) identificamos um afinamento significante das camadas internas da retina ao longo da veia temporal inferior, mas com uma área de intervalo lúcido ao redor do disco óptico. A perimetria automatizada acromática revelou um escotoma arqueado superior absoluto, poupando a fixação central em ambos os ol hos e correspondendo às áreas de atrofia ao longo das veias retinianas (boa correlação anátomo-funcional). Este padrão de envolvimento das camadas retinianas internas não havia sido descrito anteriormente. Acreditamos que o SD-OCT contribuiu significativamente para a descrição anatômica desse caso e que estes novos achados devam ser considerados e correlacionados com o estado funcional ao avaliar esses pacientes.

Descritores: Atrofia; Células ganglionares da retina; Coroide/patologia; Retina/patologia; Camada de fibras nervosas da retina; Tomografia de coerência óptica; Campo visual; Relato de caso

\section{INTRODUCTION}

Pigmented paravenous retinochoroidal atrophy (PPRCA) is a rare ocular disease that is characterized by paravenous retinal pigment epithelium (RPE) and choroidal atrophy often with overlying intraretinal bone spicule pigment deposition along retinal veins ${ }^{(1)}$. The cause is unknown, and the course of the degeneration is unpredictable. Patients are usually asymptomatic, and the diagnosis is based on the characteristic fundus appearance. Fluorescein angiography, electrophysiological and visual field tests may confirm the diagnosis ${ }^{(1)}$.

Few cases have been reported. Most of them were sporadically and detected in male patients ${ }^{(2)}$. While some reports have suggested that PPRCA has a congenital origin ${ }^{(3)}$, others suggest a primary retinal degeneration ${ }^{(2)}$. It has also been associated with mutations in the human CRB1 gene, which is known to cause other retinal dystrophies, such as retinitis pigmentosa and Coats-like exudative vasculopathy ${ }^{(4)}$. An association with Norrie's syndrome was also described. Finally, an inflammatory cause, such as syphilitic etiology, has been suggested by Hsing-Hsiang ${ }^{(5)}$.

As a rare condition, there is scant information in the literature regarding anatomical findings and about how the retinal layers are involved in PPRCA. In fact, it seems to exist a considerable variability in the extent and degree to which the retina is affected ${ }^{(2)}$. In the present case report, we provide new findings and a detailed description of the anatomical involvement of the inner retina using high-resolution retinal imaging [Spectral-Domain Optical Coherence Tomography (SD-OCT)] to evaluate a patient with PPRCA.

\footnotetext{
Submitted for publication: August 02, 2013.

Accepted for publication: October 07, 2013

Study carried out at Hospital Medicina dos Olhos, São Paulo, SP, Brazil.

Physician, Hospital Medicina dos Olhos, São Paulo (SP), Brazil;

Physician, Department of Ophthalmology, Universidade Federal de São Paulo, São Paulo (SP), Brazil.
}

Funding: No specific financial support was available for this study.

Disclosure of potential conflicts of interest: D.L.M.Junqueira, None; F.S.S.Lopes, None; L.G.Biteli, None; T.S.Prata, None.

Correspondence address: Tiago Santos Prata. Department of Ophthalmology. Universidade Federal de São Paulo. Rua Botucatu, 821 - São Paulo (SP) - 04023-062 - Brazil E-mail: tiagoprata@ig.com.br 


\section{CASE REPORT}

A 41-year-old white man was initially referred for a glaucoma evaluation, with no significant complaints. His past medical history revealed chemotherapy and radiotherapy treatment for a lymphoma two years earlier. Ophthalmological and familiar history was unremarkable. During ophthalmologic examination he presented with a best-corrected visual acuity of 20/20 in both eyes (dynamic refraction of -2.00 diopters $\mathrm{OU}$ ). Slit-lamp biomicroscopy was unremarkable. Gonioscopy disclosed a normal open angle and the intraocular pressure was $14 \mathrm{mmHg}$ OU [central corneal thickness of $540 \mu \mathrm{m}$ (OD) and $538 \mu \mathrm{m}(\mathrm{OS})$ ]. Both fundi showed patches of retinochoroidal atrophy and light pigmentation along the inferior-temporal retinal veins (Figures $1 \mathrm{~A}$ and B). The optic nerve head was well defined with 0.5 cup-to-disc-ratio and a healthy neuroretinal rim $360^{\circ} \mathrm{OU}$.

Functional evaluation (visual field test) by standard automated perimetry (Humphrey SITA-Standard 24-2, Carl Zeiss Meditec, Dublin, CA) revealed a superior absolute arcuate scotoma, sparing the central fixation in both eyes and corresponding to the areas of atrophy along the inferior-temporal retinal veins (Figures $2 \mathrm{~A}$ and $\mathrm{B}$ ). A detailed structural analysis was undertaken using the RTVue-100 SD-OCT (Optovue Inc, Fremont, CA). With the advent of this technology, a significant improvement in imaging resolution was achieved (axial resolution of $5 \mu \mathrm{m}$ in tissue and a scan speed of 26,000 A-scans/second), allowing segmentation and better identification of each retinal layer ${ }^{(6)}$. For this specific case, two scan protocols were chosen: the peripapillary retinal nerve fiber layer (RNFL) scan and the macular ganglion cell complex (GCC) scan, which comprises three inner retinal layers: the RNFL, ganglion cell layer and inner plexiform layer ${ }^{(6)}$. SD-OCT results revealed a significant thinning of the inner retinal layers (as assessed by the GCC protocol) along the inferior-temporal veins OU (average superior-inferior GCC thickness difference was $32.1 \mu \mathrm{m})$. However, the circum-peripapillary RNFL was preserved, forming a lucid interval surrounding the optic nerve head (Figures $1 C$ and D). Typical outer retina findings (previously described in the literature) were also observed. There was a good structure-functional correlation between the inferior inner retinal layers involvement (Figures 2C) and the superior functional loss documented (Figures 2A and B).

A complete systemic work-up was undertaken, including complete blood cell counts, serum electrolytes, serum protein electrophoresis and erythrocyte sedimentation rate (all within the normal range). Tuberculin skin test was negative. There was no serologic evidence of syphilis, toxoplasmosis, systemic lupus eritematosis and cytomegalovirus.

\section{DISCUSSION}

Pigmented paravenous retinochoroidal atrophy is an asymptomatic and slowly progressive disease with respect to the loss of peripheral retinal function, usually detected in a routine examination. The diagnosis of PPRCA is usually made by the characteristic fundus appearance and other causes including chorioretinal degeneration and inflammatory diseases must be ruled out ${ }^{(7)}$. Classically, the main sites of injury are the outer retinal layers and choroid, with RPE and choroidal atrophy ${ }^{(1)}$. In this case report, we have demonstrated a significant thinning of the inner retinal layers along the region of paravenous retinochoroidal atrophy (approximately 30\% thinner compared to the unaffected region) with a lucid interval surrounding the optic nerve head. In addition, these anatomical findings showed good correlation with patient's functional loss. To the best of our knowledge, this is the first report describing the pattern of inner retinal layers involvement in PPRCA with SD-OCT.
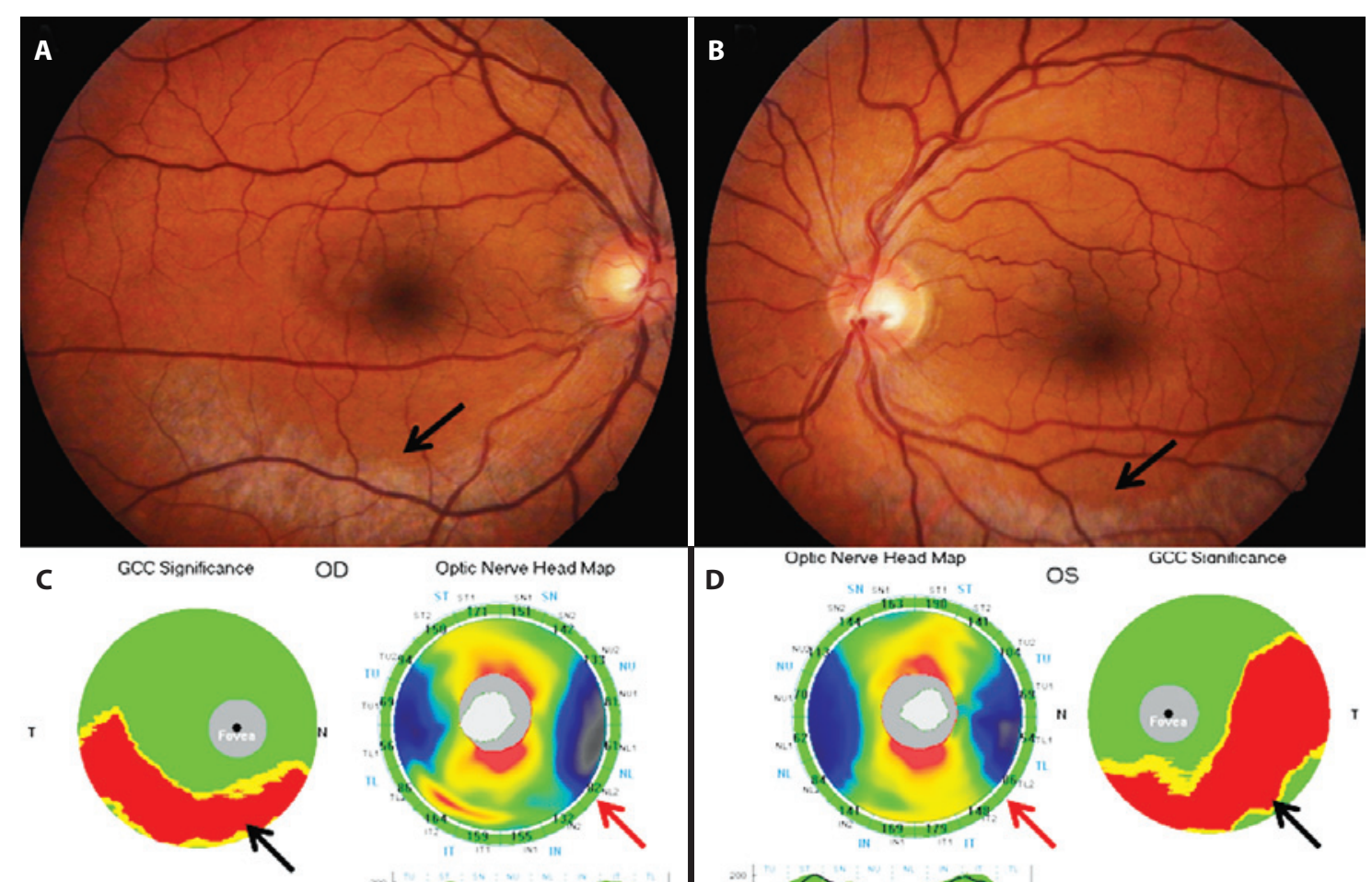

$\mathrm{OD}$

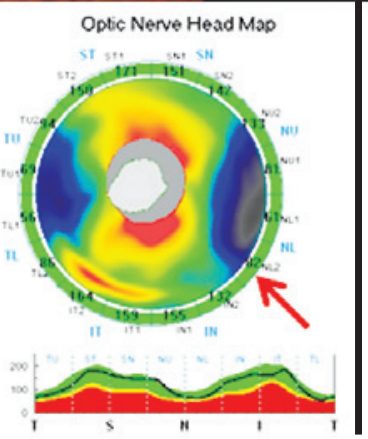

D

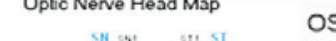

os
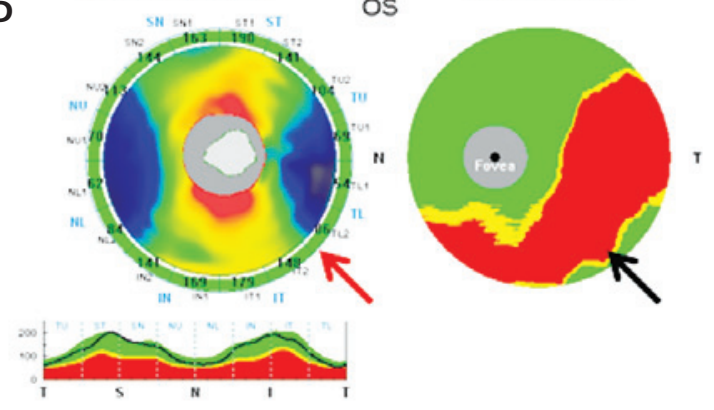

Figure 1. Fundus pictures showing patches of retinochoroidal atrophy (arrows) and pigmentation along the inferior-temporal retinal veins in both eyes (A, right eye; B, left eye). SD-OCT results showing a significant thinning of the inferior inner retinal layers (black arrows), but a normal circumperipapillary retinal nerve fiber layer (red arrows) in both eyes (C, right eye; $D$, left eye). 


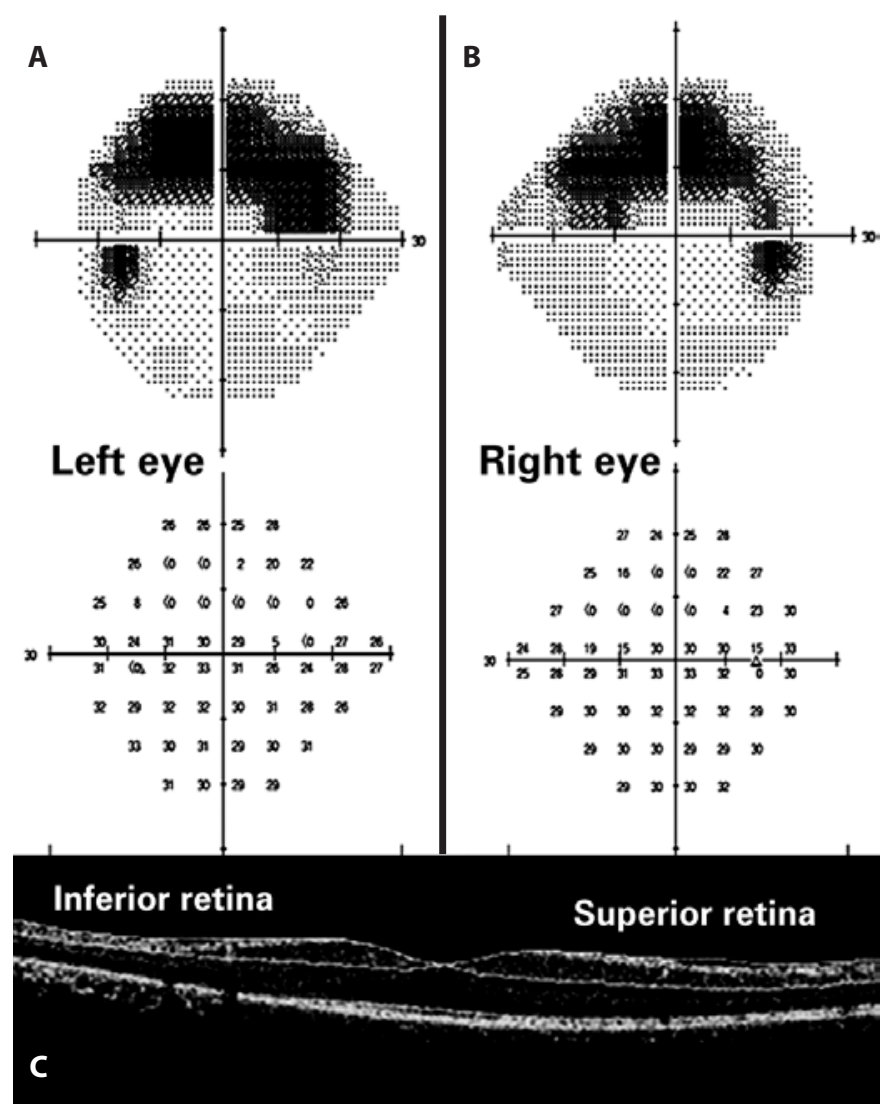

Figure 2. Functional evaluation by standard automated perimetry showing a superior absolute arcuate scotoma, sparing the central fixation in both eyes ( $A$, left eye; $B$, right eye), with a good correlation with the inferior inner retinal layers thinning documented by SD-OCT (C).

Looking carefully at the data published about the use of high-resolution imaging in cases o PPRCA, we found only two case reports in the literature. Differently form ours, the main focuses of these two publications were a detailed investigation of the outer retina ${ }^{(8)}$ and the fovea ${ }^{(9)}$. Fleckenstein et al used the SD-OCT to assess lines of increased fundus autofluorescence with a crescent-like distribution surrounding the area of RPE atrophy in a case of PPRCA ${ }^{(8)}$. These lines corresponded to the junction between a zone with preserved retinal layers on the SD-OCT scan and a zone where the presumed external limiting membrane appeared to rest directly on the RPE layer. More recently, Ghosh et al. ${ }^{(9)}$ reported on the use of the SD-OCT in a case of PPRCA, showing a lamellar macular hole in the involved eye. As none of these two cited papers reported on the GCC and peripapillary RNFL anatomy, our findings cannot be directly compared to them. However, we believe that by using high-resolution imaging, these papers as a group add significantly to the evolving knowledge about the retinal involvement in PPRCA.

In summary, using different SD-OCT protocols to investigate the pattern of inner retina involvement in PPRCA, we found a significant thinning of the inner layers, forming a lucid interval surrounding the optic nerve head. We believe SD-OCT added significantly to the anatomical description of this case, as this pattern of inner retina involvement was not previously described. From now on, we believe that these new findings should be considered and correlated with functional status while assessing patients with PPRCA.

\section{REFERENCES}

1. Choi JY, Sandberg MA, Berson EL. Natural course of ocular function in pigmented paravenous retinochoroidal atrophy. Am J Ophthalmol. 2006;141(4):763-5.

2. Kükner AS, Yilmaz T, Celebi S, Aydemir O, Ulaş F. Pigmented paravenous retinochoroidal atrophy. A literature review supported by seven cases. Ophthalmologica. 2003;217(6):436-40.

3. Noble KG. Hereditary pigmented paravenous chorioretinal atrophy. Am J Ophthalmol. 1989;108(4):365-9.

4. McKay GJ, Clarke S, Davis JA, Simpson DA, Silvestri G. Pigmented paravenous chorioretinal atrophy is associated with a mutation within the crumbs homolog 1 (CRB1) gene. Invest Ophthalmol Vis Sci. 2005;46(1):322-8.

5. Hsing-Hsiang C. Retino-choroiditis radiata. Am J Ophthalmol. 1948;41:1485-7.

6. Seong M, Sung KR, Choi EH, Kang SY, Cho JW, Um TW, et al. Macular and peripapillary retinal nerve fiber layer measurements by spectral domain optical coherence tomography in normal-tension glaucoma. Invest Ophthalmol Vis Sci. 2010;51(3):1446-552.

7. Haustrate FM, Oosterhius JA. Pigmented paravenous retinochoroidal atrophy. Doc Ophthalmologica. 1986;63(3):209-37.

8. Fleckenstein M, Charbel Issa P, Helb HM, Schmitz-Valckenberg S, Scholl HP, Holz FG. Correlation of lines of increased autofluorescence in macular dystrophy and pigmented paravenous retinochoroidal atrophy by optical coherence tomography. Arch Ophthalmol. 2008;126(10):1461-3.

9. Ghosh B, Goel N, Batta S, Raina UK. SD-OCT in pigmented paravenous retinochoroidal atrophy. Ophthalmic Surg Lasers Imaging. 2012;43(3):e41-3. 